\title{
Study on the relation between occupational fenvalerate exposure and spermatozoa DNA damage of pesticide factory workers
}

\author{
Q Bian, L C Xu, S L Wang, Y K Xia, L F Tan, J F Chen, L Song, H C Chang, X R Wang
}

Occup Environ Med 2004;61:999-1005. doi: 10.1136/oem.2004.014597

See end of article for authors' affiliations auther affiliations

Correspondence to: Dr X R Wang, Institute of Toxicology, Nanjing Medical University, Nanjing 210029, China; xrwang@njmu.edu.cn

Accepted 5 July 2004

\begin{abstract}
Aims: To determine sperm nuclear DNA integrity and to investigate the relation between fenvalerate (FE) exposure and spermatozoa DNA damage.

Methods: Sperm DNA fragmentation was detected by a modified alkaline single cell gel electrophoresis (Comet) assay and a terminal deoxynucleotidyl transferase mediated dUTP nick end labelling (TUNEL) assay. The olive tail moment (OTM) and percentage tail DNA were measured by the Comet assay, and cell positive percentage was measured by the TUNEL assay for DNA damage evaluation.

Results: The DNA integrity of spermatozoa of external and internal control groups were both significantly greater than that of the FE exposed group. The median value of tail DNA percentage in the exposure group was 11.30, which was significantly higher than 5.60 in the internal control group and 5.10 in the external control group. The median value of OTM was 3.80 in the exposure group, significantly higher than 1.50 in the internal control group and 2.00 in the external control group. Mean cell positive was $31.2 \%$ in the exposure group, significantly higher than $17.4 \%$ in the internal control and $19.6 \%$ in the external control groups. Cell positive (\%) was significantly correlated with tail DNA percentage and with OTM of whole subjects $(n=63)$.

Conclusions: Results showed that occupational FE exposure is associated with an increase in sperm DNA damage. A combination of the Comet and TUNEL assays would offer more comprehensive information for a better understanding of sperm DNA damage, and the biological significance of sperm DNA damage in sperm function and male infertility.
\end{abstract}

$\mathrm{T}$ here is a significant public health concern about the potential effects of occupational exposure to toxic substances on reproduction. Many toxicants with reported or suspected reproductive and developmental effects are still in regular commercial use and present potential exposure to workers. Several studies have shown that in some parts of the world, average sperm counts have dropped by $50 \%$ since the $1940 \mathrm{~s}^{1{ }^{2}}$ Occupational exposure and environmental exposure to hazardous substances have been conjectured as one of the aetiologies of sperm number decline. $^{3}$

Pesticides have been used in developing nations to eradicate insect borne endemic diseases for food production and forested plantations protection. Pesticide application has increased in recent years, resulting in more pesticide production. ${ }^{45}$ Nevertheless, several currently used pesticides, especially those having endocrine disruptive properties, are known to adversely impair reproductive competence of males working in laboratories, fields, clinics, or factories. ${ }^{67}$ Pesticide factory workers have a higher exposure risk and are more prone to the damage made by pesticides. There have been few investigations of potential genotoxic effects in pesticide industry workers. In China, pesticide production is a yearround activity, and pesticide industry workers log in 40 hours a week. These workers have constant exposure to a variety of pesticides such as pyrethroids (fenvalerate), organophosphorus compounds (phoxim), and carbamates (carbaryl). However, there have been few reports of genetic damage in occupational populations exposed to pesticides in China.

Fenvalerate (FE, 4-chloro- $\alpha$-(1-methylethyl)benzeneacetic acid cyano(3-phenoxyphenyl)methyl ester) is a synthetic pyrethroid insecticide which is widely used for fruit and vegetable protection due to its strong neurotoxic activity for insects but low toxicities for mammals, birds, and plants.
Evidence from general population exposure studies and in vitro studies suggests that FE is hormonally active. ${ }^{8}$ Reports from animal studies have shown that FE and testicular toxicity are associated. It is known that FE induces a significant reduction in testes weight, epididymal sperm count, sperm motility, and marker testicular enzymes for testosterone biosynthesis. ${ }^{9}$ This conclusion generated both public health and scientific concern about potential reproductive effects of FE.

A lack of consensus on which semen quality tests are the best predictors of human male fecundity has led to the development of several new methods to evaluate semen quality. The traditional semen analysis focused on measurements for sperm concentration, motility, and morphology. ${ }^{10}$ Although these analyses may describe some aspects of the function of the testis and sperm, they do not address the integrity of the male genome contained in the sperm head. Alkaline single cell gel electrophoresis (SCGE) assay or Comet assay and terminal deoxynucleotidyl transferase mediated dUTP-biotin end labelling (TUNEL) assay have also been used to evaluate sperm DNA damage. ${ }^{11-13}$

Comet assay is a visual fluorescent technique for measurement of DNA strand breaks in individual cells. The Comet assay was chosen as it gave detailed information on the quantitation of individual sperm DNA integrity. This method depends on unwinding of nuclear DNA under alkaline conditions, following electrophoresis that draws out the broken strands of DNA. These strands form a tail in one side of the sperm head (nucleus) that has been characterised as a "Comet" image. The DNA can be quantified using image analysis software.

The TUNEL assay was originally designed for measuring DNA fragmentation during apoptosis. ${ }^{14}$ Fragmentation of genomic DNA is an initial hallmark of apoptosis. Apoptosis 
can be detected in somatic cells by electrophoresis of DNA fragments; it has been characterised as a "ladder" pattern due to endonuclease cuts in the linker section of the helix. However, this analysis is not possible for spermatozoa due to the presence of protamines in sperm. By using the FCM TUNEL assay, DAN fragments can be detected in damaged sperm. Recently the TUNEL technique has been widely used for detection of DNA strand breaks in human sperm. ${ }^{13}{ }^{15-18}$

The aim of this study is to conduct risk assessments of pesticide manufacturing factories using both Comet and TUNEL assays to determine nuclear DNA integrity and the DNA fragmentation level of spermatozoa in FE exposed workers, and to determine the correlation between these two methods.

\section{Study population}

The Changzhou pesticides factory is located in a suburb of Changzhou city in southeast China and has been in operation since the 1970s. The factory is divided into two areas: production area and office area. The production area has four major production plants including those for fenvalerate (FE), carbaryl, buprofezin, and imidacloprid. The factory employs about 400 workers (265 men and 135 women). The FE production plant has 86 workers ( 56 men and 30 women). FE production workers were the exposed subjects in our study. Men from the office area of the same factory were used as internal controls. Volunteers recruited from different departments at the local board of health, which is located in the urban district of Changzhou city were used as an external reference for comparison.

Based on the production process and environmental monitoring data, these workers were exposed to low levels of FE. We used a CD-1 air sampler (Beijing Detection Instrument Factory, Beijing, China) to detect the air concentration of FE at different areas of three groups for three days continuously. At the end of each work shift, we conducted an exposure assessment on three randomly selected subjects per day for three days. This assessment consisted of two components: individual sampling using active personal samplers (Xinyu Analysis Instrument Factory, Jiangsu, China); and measurement of dermal contamination by attaching fibrous filter membranes to 10 body areas. Our monitoring indicated that the mean concentration of FE was $21.55 \times 10^{-4} \mathrm{mg} / \mathrm{m}^{3}$ at operation sites. The mean concentration of FE was $1.19 \times 10^{-4} \mathrm{mg} / \mathrm{m}^{3}$ at the internal control area and was not detected at the external control area. The concentration of FE in the workplace was significantly higher than concentrations in control areas $(p<0.001)$. Simultaneously, the concentrations of FE with individual sampling (mean concentration $0.11 \mathrm{mg} / \mathrm{m}^{3}$ ) and dermal contamination (mean concentration $1.59 \mathrm{mg} / \mathrm{m}^{2}$ ) detected in the FE exposure area were significantly higher than those in control areas $(\mathrm{p}<0.01)$.

\section{Subjects and selection}

All participants in this study were volunteers. All subjects were asked to complete a face-to-face questionnaire which included standard demographic data (age, gender, etc) as well as medical history ( $x$ ray exposure, vaccinations, medications, etc), lifestyle (smoking status, coffee and alcohol intake, diet, etc), and occupational conditions (daily working hours, years of exposure, use of protection, etc). All subjects were male aged 22-45 years.

All of the $56 \mathrm{FE}$ exposed men were considered for study, but 22 proved ineligible because they had worked less than a year in total or less than six months continuously before study. A further six were excluded, based on questionnaire responses, because of their past medical history (liver or renal disease, long term psychotropic drug therapy, significant $x$ ray exposure, or recent exposure to other neurotoxic drugs). Among the remaining 28 men, 21 took part in the study. Controls were selected from the same district and were matched on socioeconomic class. Two control groups were used. An internal group was recruited from clerical or office workers of the same company who worked at least a mile away from the pesticide plant and had never been exposed to pesticides at work. Altogether, 38 subjects were invited, but five were excluded on medical history (using the same criteria as for exposed workers), and 23 of the remaining 33 subjects agreed to participate. In addition an external control group was recruited from men working for the local board of health. We approached 33 subjects, of whom 23 completed a preliminary questionnaire. Four were excluded from investigation, based on medical history, so 19 subjects participated. Table 1 summarises the demographic characteristics of the three study groups.

The study was approved by the local ethics committee. Informed consent for participation was obtained from each individual, and an IRB (Institutional Review Board) approval was given prior to the beginning of this study.

\section{Semen sample collection and analysis}

All semen samples from subjects were obtained by masturbation into sterile containers after abstinence from sexual activity for 3-5 days. After liquefaction at $37^{\circ} \mathrm{C}$ for 30 minutes, a routine semen analysis ${ }^{10}$ and sperm motility test were carried out by light microscopy and computer assisted sperm analysis (CASA) to provide details of sperm concentration and motility within 30 minutes. Sperm number was determined using a micro-cell slide. Sperm motility parameters were determined for sperm tracts: curvilinear velocity (VCL, $\mu \mathrm{m} / \mathrm{s}$; a measure of the total distance travelled by a given spermatozoon divided by the time elapsed); average path velocity (VAP, $\mu \mathrm{m} / \mathrm{s}$; the average velocity of sperm movement; spermatozoa were counted as exhibiting rapid progressive motility if VAP $>25 \mu \mathrm{m} / \mathrm{s}$ ); straight line velocity (VSL, $\mu \mathrm{m} / \mathrm{s}$; the straight line distance from beginning to end of a sperm track divided by the time taken); beat cross frequency $(\mathrm{BCF}, \mathrm{Hz}$; the frequency of the sperm head crossing the sperm average path); amplitude of lateral head displacement (ALH); straightness (STR, \%); and linearity (LIN, \%).

Strict quality control measures were enforced throughout the whole study. Each sample was assessed twice in parallel. For instance, sperm concentration was detected twice and the difference (D) between two results was calculated according to a formula $(\mathrm{D}(\%)=(\operatorname{Max}-\operatorname{Min}) / \mathrm{Min} \times 100 \%)$. If $\mathrm{D} \leqslant 15 \%$, use the mean value of two results to express the final value; if D $>15 \%$, test the sample three times and use the median value of three results as the final value. Semen samples with known sperm parameters were used on a regular basis for quality assessment.

After freezing in $1 \mathrm{ml}$ cryogenic straws by immersing the straws directly into liquid nitrogen $\left(-196^{\circ} \mathrm{C}\right)$ for 24 hours, the remaining raw semen was stored in a refrigerator at $-70^{\circ} \mathrm{C}$ until the Comet and TUNEL assays were performed.

\section{Comet assay}

The modified Comet assay for sperm was carried out using the method described by Hughes (1998) and Donnelly (1999), which was based on that initially reported by Singh (1996). ${ }^{19-21}$ All steps were carried out under yellow light to prevent further DNA damage. The straws were thawed by gently shaking in a $37^{\circ} \mathrm{C}$ water bath for 10 seconds, and the semen was immediately processed for assay. After thawing, sperm were washed with $\mathrm{Ca}^{2+}$ and $\mathrm{Mg}^{2+}$ free phosphate buffered saline (PBS) twice $\left(1500 \mathrm{~g} \times 5 \mathrm{~min}, 4^{\circ} \mathrm{C}\right)$, and resuspended in PBS at $2 \times 10^{6}$ cells/ml. Agarose solutions of 
Table 1 Characteristics and conventional semen parameters of the study population $(n=63)$

\begin{tabular}{|c|c|c|c|c|c|}
\hline Parameters & $\begin{array}{l}\text { Exposure } \\
(\text { mean } \pm S D) \\
(n=21)\end{array}$ & $\begin{array}{l}\text { Internal controls } \\
\text { (mean } \pm S D) \\
(n=23)\end{array}$ & $P_{1}$ & $\begin{array}{l}\text { External controls } \\
\text { (mean } \pm S D) \\
(n=19)\end{array}$ & $\mathbf{P}_{2}$ \\
\hline Age (y) & $30.13 \pm 9.61$ & $29.07 \pm 6.91$ & 0.655 & $30.61 \pm 6.56$ & 0.846 \\
\hline Working history (y) & $9.22 \pm \overline{7} .68$ & $6.56 \pm 5.03$ & 0.057 & $8.49 \pm 6.11$ & 0.890 \\
\hline \multicolumn{6}{|l|}{ Smoking status } \\
\hline $\begin{array}{l}\text { Non-smoker (\%) } \\
\text { Smoker (\%) }\end{array}$ & $\begin{array}{l}9(42.9) \\
12(57.1)\end{array}$ & $\begin{array}{l}11(47.8) \\
12(52 ?)\end{array}$ & 0.741 & $9(47.4)$ & 0.775 \\
\hline Smoking years & $8.43 \pm 5.68$ & $7.12 \pm 4.98$ & 0.804 & $7.78 \pm 6.01$ & 0.852 \\
\hline \multicolumn{6}{|l|}{ Semen parameters } \\
\hline Sperm concentration (million/ml) & $52.89 \pm 35.04$ & $52.92 \pm 36.94$ & 1.00 & $59.78 \pm 17.02$ & 0.830 \\
\hline Subjects $<20$ million sperm $/ \mathrm{ml}(\%)$ & $2(9.50)$ & $2(8.7 \overline{5})$ & 0.924 & $2(10.52)$ & 0.916 \\
\hline Sperm motility (\% motile) & $55.73 \pm 11.88$ & $57.20 \pm 10.53$ & 0.713 & $56.42 \pm 16.17$ & 0.868 \\
\hline Subjects $<50 \%$ motile sperm (\%) & $4(19.03)$ & $7(30 . \overline{3} 7)$ & 0.384 & $7(36 . \overline{8})$ & 0.208 \\
\hline
\end{tabular}

normal and low gel points were prepared at $0.75 \%$ concentrations for slide preparations. Slides were covered with $80 \mu \mathrm{l}$ normal melting agarose (NMA), and coverslips were applied on the gel at $4^{\circ} \mathrm{C}$ for 10 minutes to allow solidification. The coverslips were then removed. A total of $1 \times 10^{5}$ cells in $10 \mu \mathrm{l}$ PBS were mixed with $65 \mu \mathrm{l}$ low melting point agarose (LMA) and allowed to solidify to form a second layer at $4^{\circ} \mathrm{C}$ for 10 minutes. After removal of the coverslips, a third layer containing $75 \mu \mathrm{LMA}$ was added and allowed to solidify. The coverslips were removed and the slides were placed in coupling jars containing freshly prepared cold lysis buffer $\left(2.5 \mathrm{M} \mathrm{NaCl}, 100 \mathrm{mM} \mathrm{Na}{ }_{2}\right.$ EDTA, $10 \mathrm{mM}$ Tris, $10 \%$ DMSO, and $1 \%$ Triton X-100, pH 10), and the slides were incubated at $4^{\circ} \mathrm{C}$ for at least one hour. Slides were then incubated with $10 \mathrm{mmol} / \mathrm{l}$ dithiothreitol (DTT; Sigma) for one hour at $4^{\circ} \mathrm{C}$, and transferred to $37^{\circ} \mathrm{C}$ for another one hour incubation with $200 \mu \mathrm{g} / \mathrm{ml}$ proteinase K (Sigma) in order to decondense DNA and eliminate the effect of protamines.

The slides were then removed and placed on a horizontal gel electrophoresis unit side by side. The unit was filled with freshly prepared alkaline buffer $(300 \mathrm{mmol} / \mathrm{l}$ sodium acetate and $100 \mathrm{mmol} / \mathrm{l}$ Tris, $\mathrm{pH} \mathrm{10)}$ up to $0.25 \mathrm{~cm}$ above the slides. The cells were exposed to alkaline conditions for 20 minutes to allow the DNA to unwind and to express single strand breaks and alkali labile sites. Electrophoresis was then conducted for one hour by applying an electric current of $0.46 \mathrm{~V} / \mathrm{cm}(12 \mathrm{~V} / 100 \mathrm{~mA})$ at $12-15^{\circ} \mathrm{C}$, to allow damaged DNA to migrate from the nucleus towards the anode. Slides were then drained, placed on a tray, and washed slowly with three changes of neutralisation buffer (0.4 M Tris-HCl, $\mathrm{pH}$ 7.5) for five minutes. DNA was then precipitated and slides were dehydrated in absolute methanol for 10 minutes and left to dry at room temperature.

Slides were stained with $50 \mu \mathrm{l}$ ethidium bromide (EB, $15 \mu \mathrm{g} / \mathrm{ml}$ ) prior to scoring. Fluorescent Comet patterns were then examined with an Olympus fluorescence microscope equipped with an excitation filter of $515-560 \mathrm{~nm}$ and a barrier filter of $590 \mathrm{~nm}$ under $400 \times$. Slides were arranged and coded randomly to blind the scorer. The person who analysed the slides was blinded to exposure status. All slides were snapped and analysed by one person, to avoid interscorer variability.

\section{Image analysis}

Percentage DNA in tail and olive tail moment (OTM) on 100 sperms in each semen sample (two duplicate sample slides, 100 randomly selected cells scored per slide, up to 200 sperms in total) were measured using CASP image analysis software. ${ }^{22}$ Percentage DNA in the tail is a measurement of the proportion of the total DNA present in the tail. The OTM, expressed in arbitrary units, has been calculated by multiplying the percentage of DNA (fluorescence) in the tail by the length of the tail in $\mu \mathrm{m}$ and to measure sperm DNA damage degree. ${ }^{23}$ The tail length was measured between the edge of the Comet head and the end of the Comet tail. The OTM is an integrated value that takes into account both the distance and intensity of Comet fragments.

\section{TUNEL assay}

An FITC labelled dUTP system (an in situ cell death detection kit from Roche) was applied to measure sperm DNA fragmentation. Samples were washed and sperm suspensions prepared as for Comet assay. Sperm cells (about $3 \times 10^{6}$ spermatozoa) were fixed in $2 \%$ paraformaldehyde (30 minutes, RT). If the number of available spermatozoa was below 3 million, the sample was concentrated through centrifuging. Fixed cells were washed with PBS once, and resuspended in $100 \mu \mathrm{l}$ permeabilisation solution $(0.1 \%$ Triton $\mathrm{X}-100,0.1 \%$ sodium citrate) for 10 minutes on ice. The samples were then washed with PBS once and cells were resuspended in $50 \mu \mathrm{l} \mathrm{TdT}$ reaction solution containing nucleotides and TdT enzyme. One tube of control sample was kept as a negative control without enzyme addition. The samples were incubated in a humidified chamber for 60 minutes at $37^{\circ} \mathrm{C}$ in the dark. At the end of incubation, sample were centrifuged and cells were resuspended in PBS for flow cytomety (FCM) analysis after the reaction solution was discarded. The samples were analysed using FCM with an air cooled argon $488 \mathrm{~nm}$ laser and a $550 \mathrm{~nm}$ dichroic mirror as detectors. At least 10000 cells were collected in each group. The obtained data were finally analysed using cell quest software (version 3.2.1, Becton Dickinson Imunocytometry systems) for calculating the percentage of FITC labelled dUTP positive cells.

Using DNase I as the positive control, we found that treatment of DNase I with sperm cells resulted in a significant increase of spermatozoa labelled with FITC. A normal sample was detected as a negative control.

\section{Statistical analysis}

SPSS for Windows (version 10.0) was used for data analysis, to perform descriptive analysis for subject characteristics, and to examine distribution of the variables. Since the OTM and percentage DNA in the tail did not follow a Gaussian distribution, data in Comet assay were presented as median values. Differences of OTM and percentage DNA in the tail between groups were determined using the Mann-Whitney U test. Differences of semen parameters, CASA values, and cell positive (\%) between groups were determined using the LSD test of ANOVA. A $p$ value of $\leqslant 0.05$ was considered statistically significant in every test. Relations between OTM and cell positive, and between percentage DNA in tail and cell positive of all subjects were determined using 
Kendall's rank correlation analysis because OTM and tail DNA percentage did not have Gaussian distribution.

\section{RESULTS}

\section{Semen analysis}

Table 1 shows that mean ages and mean working years of the subjects in the internal and external control groups were significant difference in smoking status among these three groups. In the exposure group, two of $21(9.50 \%)$ were oligozoospermic $\left(<20 \times 10^{6} / \mathrm{ml}\right)$, and four of $21(19.03 \%)$ had low motility by WHO standards $(<50 \%)$. Two of $23(8.75 \%)$ and two of $19(10.52 \%)$ had abnormal values for sperm concentration $\left(<20 \times 10^{6} / \mathrm{ml}\right)$ in internal and external controls. Seven of $23(30.37 \%)$ and seven of $19(36.82 \%)$ in the internal and external control groups fell below the WHO threshold of $50 \%$ motility. The differences in sperm concentration and motility in the three groups were not statistically significant. Table 2 shows that STR was 75.42 in the FE exposed group, which was significantly lower than 80.21 in the external controls. However, no significant difference in STR between the FE exposed group and the internal control group was observed. There were no significant differences in BCF, ALH, LIN, VAP, VCL, and VSL between the FE exposed group and the two control groups. No significant difference was observed in semen concentration or sperm motility between the exposure group and the two control groups.

\section{Comet assay}

Results showed that DNA strand breakage was detected in 21 FE exposed workers using a Comet assay (table 3 and fig 1 ). percentage DNA in the tail was 11.30 in the exposure group, which was significantly higher than the internal control group (5.60) and external control group (5.10). The median value of OTM was 3.80 in the exposure group, significantly higher than the internal control group (1.50) and external control group (2.00). similar to those in the FE exposed group. There was no These results also showed that the median value of

\section{TUNEL assay}

DNA fragmentation was analysed among 21 FE exposed workers using a TUNEL assay. Results showed the mean cell positive was $31.18 \%$ in the exposure group, which was significantly higher than $17.39 \%$ in the internal control and $19.58 \%$ in the external control groups (table 3). Less than $4 \%$ of cells in the negative control samples showed signals. More than $96 \%$ of cells in the positive control samples showed signals. Figure 2 shows a typical example of cells stained with FITC labelled dUTP.

\section{Relation between Comet and TUNEL assays}

There was a significantly positive correlation between the degree of DNA damage determined using the Comet assay and the percentage of DNA fragmentation determined using the TUNEL assay. Cell positive (\%) was correlated with tail DNA percentage $($ tau $=0.56, \mathrm{p}<0.01$, fig 3 ) and with OTM ( tau $=0.56, p<0.01$, fig 4$)$ of all the subjects $(n=63)$. These associations did not diminish even after adjusting for potential confounders such as smoking with linear regression. Nevertheless, no association was found between these values of damaged sperm DNA and various semen parameters or CASA profiles.

\section{DISCUSSION}

Results indicated that occupational exposure to FE induced a significant increase in sperm DNA damage. To our knowledge, this is the first in vivo observation using the Comet assay and TUNEL assay for genotoxic potential for workers handling FE. Specifically, there was a significant positive association between FE exposure and percentage DNA in the tail, OTM, and positive sperm damage.

Pesticide exposure has been associated with considerable changes in sperm parameters, suggesting that the testicle is one of the most vulnerable organs to environmental physical and chemical agents. ${ }^{24}$ Swan and colleagues reported that sperm concentration was reduced and sperm motility decreased in fertile men in an agrarian area relative to men in an urban area in the USA. ${ }^{25}$ In a subsequent study they
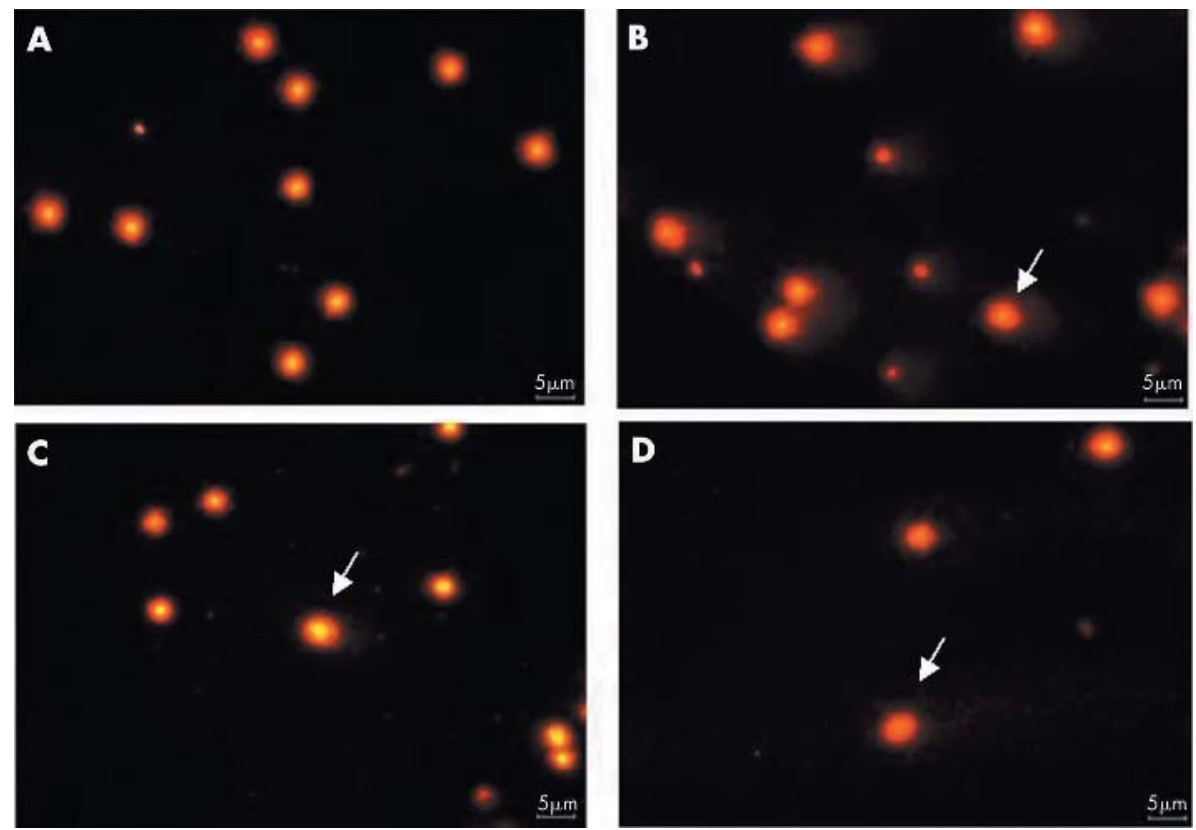

Figure 1 Sperm cells processed using single cell gel electrophoresis (Comet) assay. (A) Intact cells with undamaged DNA (without comet tail) in control group. (B) Cells with minor DNA damage (short Comet tails) in exposed group. (C) Cells with moderate DNA damage (considerable heterogeneity of Comet tail lengths within an individual) in exposed group. (D) Cells with major DNA damage (long Comet tails) in exposed group. Scale bar $=5 \mu \mathrm{m}$. 
Table 2 Comparison of computer assisted sperm analysis (CASA) profiles between the FE exposed group and control groups $(n=63)$

\begin{tabular}{|c|c|c|c|c|c|}
\hline CASA & $\begin{array}{l}\text { Exposures } \\
(\text { mean } \pm S D) \\
(n=21)\end{array}$ & $\begin{array}{l}\text { Internal controls } \\
(\text { mean } \pm \text { SD) } \\
(n=23)\end{array}$ & $P_{1}$ & $\begin{array}{l}\text { External controls } \\
(\text { mean } \pm S D) \\
(n=19)\end{array}$ & $\mathbf{P}_{2}$ \\
\hline $\mathrm{BCF}(\mathrm{Hz})$ & $4.59 \pm 1.38$ & $4.57 \pm 1.18$ & 0.971 & $4.77 \pm 1.45$ & 0.671 \\
\hline $\mathrm{ALH}(\mu \mathrm{m})$ & $11.29 \pm 2.61$ & $11.67 \pm 2.63$ & 0.632 & $11.19 \pm 2.34$ & 0.904 \\
\hline LIN (linearity) & $41.55 \pm 6.69$ & $42.71 \pm 7.93$ & 0.592 & $45.33 \pm 6.63$ & 0.079 \\
\hline STR (straightness) & $75.42 \pm 8.14$ & $77.92 \pm 7.75$ & 0.270 & $80.21 \pm 5.67$ & 0.041 \\
\hline $\operatorname{VAP}(\mu \mathrm{m} / \mathrm{s})$ & $38.71 \pm 5.58$ & $38.34 \pm 5.11$ & 0.832 & $39.01 \pm 6.62$ & 0.866 \\
\hline $\mathrm{VCL}(\mu \mathrm{m} / \mathrm{s})$ & $73.99 \pm 18.05$ & $72.84 \pm 16.54$ & 0.834 & $71.30 \pm 16.82$ & 0.628 \\
\hline $\operatorname{VSL}(\mu \mathrm{m} / \mathrm{s})$ & $30.82 \pm 11.41$ & $29.53 \pm 6.40$ & 0.630 & $31.00 \pm 7.95$ & 0.947 \\
\hline
\end{tabular}

$P_{1}$ compared with internal controls; $P_{2}$ compared with external controls.

BCF, beat cross frequency; ALH, amplitude of lateral head displacement; LIN, linearity; STR, straightness; VAP, average path velocity; VCL, curvilinear velocity; VSL, straight line velocity.

addressed the hypothesis that pesticides used in agriculture in the Midwest contributed to these differences in semen quality. Agricultural chemicals were found to reduce semen quality in fertile men. ${ }^{26}$ Padungtod and colleagues investigated the association between occupational pesticide exposure and semen quality among Chinese workers, and found a significant reduction of sperm concentration and percentage of motility. These results suggested that occupational exposure to pesticides has a moderately severe adverse effect on semen quality. ${ }^{27}$ Another recent study suggested that exposure to ICON, one of the pyrethroid insecticides, may disrupt male reproductive function and cause sexual dysfunction in male rats. ${ }^{28}$

There are a few reports concerning FE induced male reproductive effects in laboratory animals, including previous works in our laboratory. ${ }^{29}$ However, whether FE may induce male reproductive toxicity in FE exposed workers has not been evaluated.

Based on the industrial hygiene monitoring data collected in this study, the average concentration of FE in manufacturing units was in the range 6.76-797.54 $\times 10^{-4} \mathrm{mg} / \mathrm{m}^{3}$. Exposed workers mainly take in FE through dermal absorption and inhalation. The genetic damage observed in this study might be due to insufficient protection applied to the workers.

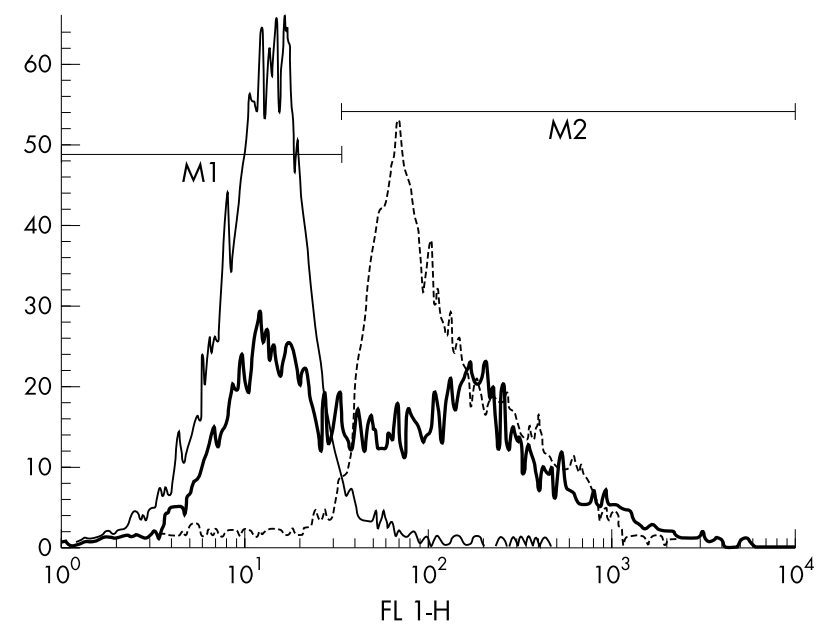

Figure 2 Histograms of TUNEL assay for human spermatozoa analysed by flow cytometry. Left peak: control group with $4 \%$ TUNE -positive cells (DNA fragmentation). Right peak: sperm cells treated with 2.5 units DNase I in the reaction buffer $(40 \mathrm{mM}$ Tris- $\mathrm{HCl}, 10 \mathrm{mM} \mathrm{NaCl}, 6 \mathrm{mM}$ $\mathrm{MgCl}_{2}, 10 \mathrm{mM} \mathrm{CaCl}$, $\mathrm{pH}$ 7.9) for 30 min at room temperature, which resulted in a significant increase of TUNEL positive cells $(96 \%)$. Lowest peak: sperm sample from an FE exposed worker with 54.6\% TUNEL positive cells.
The data presented here provide evidences of an important relation between occupational FE exposure and sperm DNA fragmentation. Exposure to known genotoxic compounds could induce DNA damage directly and through other mechanisms, such as oxidative stress or inflammatory processes. ${ }^{30}$ At present, two hypotheses have been proposed to explain the possible origin of sperm DNA damage: incomplete maturation during spermiogenesis and apoptosis. ${ }^{31}$

DNA damage may result in cell death or induction of mutations. In sperm, DNA damage may carry mutations into the next generation or result in male infertility. DNA integrity may become more important in evaluating sperm health for male infertility. However, some dormant DNA damage cannot be detected by the present techniques. The DNA damage may only be reflected through congenital abnormalities in offspring.

DNA damage due to apoptosis has been found to occur in the testis during spermatogenesis, predominately at the spermatogonia and dividing cells level. ${ }^{31-34}$ The increased sensitivity to DNA damage in abnormal spermatozoa is probably due to failed chromatin condensation, which makes the DNA more accessible to damage. ${ }^{31}$ Therefore, the presence of DNA fragmentation in ejaculated spermatozoa might correlate with defects in spermatogenesis, as has been suggested by Gandini and colleagues. ${ }^{36}$ The presence of DNA fragmentation is also increased in spermatozoa of poor quality as measured using the TUNEL or Comet assay. ${ }^{13} 3738$

Biomarkers of the genetic integrity of sperm are designed to identify risks for paternally mediated developmental effects. The prevalence of DNA strand breaks or DNA fragmentation in human sperm closely correlated with sperm functions such as sperm motility, sperm-oocyte fusion ability, in vitro fertilisation or intracytoplasmic sperm injection fertilisation rate, and routine seminal parameters such as sperm morphology and concentration. ${ }^{13} 171839$ However, our results did not show any significant relation between the results from the Comet or TUNEL assays and traditional semen parameters or CASA profiles. Therefore, it appeared that sperm DNA damage, which may be indicative of the early stages of damage, was detectable using the Comet or TUNEL assay when there were no other indications such as significant changes in sperm motility and concentration.

Technically, both the Comet and TUNEL assays are used to measure DNA strand breaks. Aravindan and colleagues applied these two tests in a group of infertile patients and found that results from these two assays were highly correlated. ${ }^{15}$ Moreover, it is also noted that results from the Comet and TUNEL assays were also strongly correlated with other techniques used for measuring DNA damage, such as the sperm chromatin structure assay (SCSA) and in situ nick translation assay. Recently, a number of studies have 
Table 3 Comparison of percentage DNA in tail, OTM of Comet sperm, and cell positive (\%) in situ nick translation condensed by TUNEL assay between FE exposed workers and controls

\begin{tabular}{llllll}
\hline Variables & Exposure $(\mathbf{n}=\mathbf{2 1})$ & Intra-control $(\mathbf{n}=\mathbf{2 3})$ & $\mathbf{P}_{\mathbf{1}}$ & Extra-control $(\mathbf{n}=19)$ & $\mathbf{P}_{\mathbf{2}}$ \\
\hline Comet assay & $11.30(2.85-18.45)$ & $5.60(1.98-10.5)$ & 0.044 & $5.10(1.50-7.10)$ & 0.024 \\
\% DNA in tail & $3.80(1.10-5.90)$ & $1.50(0.65-3.05)$ & 0.016 & $2.00(0.60-2.80)$ & 0.011 \\
OTM & $31.18 \pm 18.38$ & $17.39 \pm 13.37$ & 0.005 & $19.58 \pm 14.39$ & 0.016 \\
TUNEL assay & Cell positive (\%) & & &
\end{tabular}

Percentage DNA in tail and OTM shown as median value. Cell positive (\%) shown as mean \pm SD.

$\mathrm{P}_{1}$ compared with internal controls; $\mathrm{P}_{2}$ compared with external controls.

discussed the methodology of the Comet assay in human spermatozoa; it is generally believed that the Comet assay is a simple, inexpensive, reliable, and reproducible technique for assessing DNA damage in sperm. ${ }^{21} 23374041$ At the same time, Host and colleagues discovered that infertile patients had higher levels of DNA strand breaks than fertile subjects using the TUNEL assay, confirming the diagnostic value of this technique in evaluation of sperm function and male fertility. ${ }^{33}$ The TUNEL assay based on FCM allows measurement of DNA damage at the single cell level, as well as automatic analysis of thousands of cells in a few seconds. Compared with the Comet assay, the TUNEL assay is more expensive. However, the Comet assay failed to detect significant differences in baseline levels of DNA strand breaks between normozoospermic fertile, normozoospermic infertile, and asthenozoospermic infertile subjects. ${ }^{19}{ }^{41}$

Due to inherent technical limitations in these tests, it is believed that a combination of Comet and TUNEL assays will offer more complete information for a better understanding of DNA damage and its biological significance in male infertility. Further research is needed to make these tests more practical and more effective, and to determine their ultimate utility for hazard identification and elucidation of modes and mechanisms of toxicant action.

Biomonitoring studies of populations exposed to pesticides are rather specific because different populations have different lifestyles, nutritional habits, and climatic and environmental conditions, and are exposed to different pesticides. It is why some studies have found an increase in genetic damage in populations exposed to pesticides while other studies showed negative results. Since sperm DNA damage is an important step from spermatogenesis to malfunction such as infertility, our study represents an important evaluation for the potential health risks associated with agrochemical exposure.

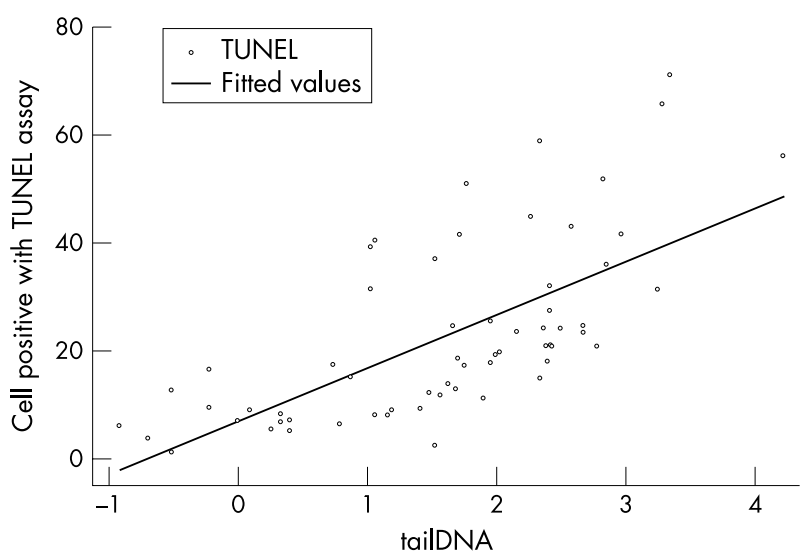

Figure 3 Correlation between cell positive (\%) and tail DNA percentage of 63 subjects $(r=0.56, p<0.01)$. Tail DNA percentage values were transformed to log values.

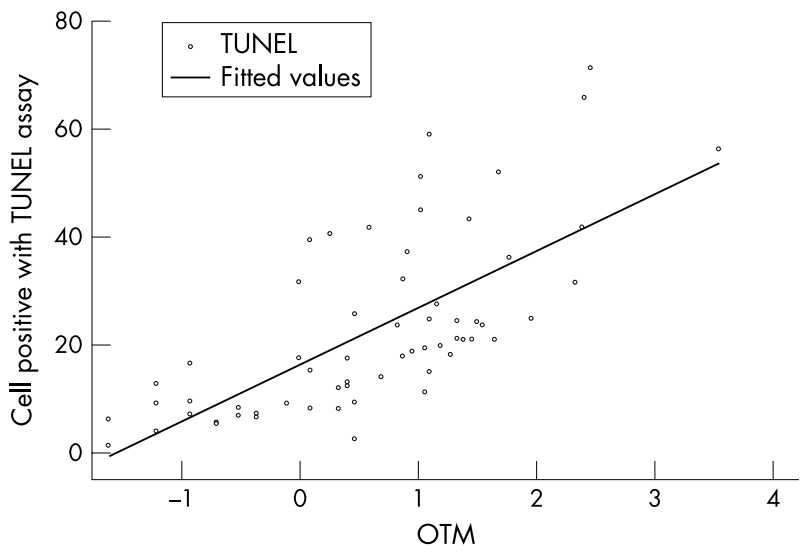

Figure 4 Correlation between cell positive (\%) and OTM of 63 subjects $(r=0.56, p<0.01)$. OTM values were transformed to log values.

In summary, sperm DNA strand breaks were observed in FE exposed workers using both the Comet and TUNEL assays. It was suggested that occupational exposure to FE induced sperm DNA damage. Since damage levels were based on a single semen sample from limited subjects $(n=63)$, our conclusion needs to be clarified with further larger scale studies. Our research is the first epidemiological study to explore the association between FE exposure and sperm DNA integrity at occupational population levels. In addition, results of the TUNEL assay were significantly correlated with those of the Comet assay. This study showed that combination of the Comet assay and TUNEL assay is a potentially useful tool for detection of DNA damage in human sperm for epidemiological studies.

\section{ACKNOWLEDGEMENTS}

This project was supported by the National Key Basic Research and Development Program of China (2002 CB512908); and a Specific Grant of the National Key Basic Research Program of China (200150)

\section{Authors' affiliations}

Q Bian, L C Xu, Y K Xia, J F Chen, L Song, H C Chang, X R Wang, Institute of Toxicology, Nanjing Medical University, Nanjing, 210029, China

S L Wang, Division of Environmental and Occupational Health, University of Medicine \& Dentistry of New Jersey, Piscataway, NJ 08854, USA

L F Tan, Changzhou CDC, Changzhou, 213003, China

Grant sponsors: National Key Basic Research and Development Program of China: 2002 CB512908; Specific Grant of National Key Basic Research Program of China: 200150.

\section{REFERENCES}

1 Carlsen E, Giwercman A, Keiding N, et al. Evidence for decreasing quality of semen during the past 50 years. BMJ 1992;305:609-13. 
2 Auger J, Kunstmann JM, Czyglik F, et al. Decline in semen quality among fertile men in pairs during the past 20 years. N Engl J Med 1995;332:281-5.

3 Bigelow PL, Jarreil J, Young MR, et al. Association of semen quality and occupational factors: comparison of case-control analysis and analysis of continuous variables. Fertil Steril 1998:69:11-18.

4 WHO/UNEP Working Group. Public health impact of pesticides used in agriculture. Geneva: World Health Organisation, 1990.

5 Health impacts of pesticide exposure and approaches to prevention. http:// www.occuphealth.fi/e/info/asin/ap399/health02.htm.

6 Figa-Talamanca I, Traina ME, Urbani E. Occupational exposures to metals, solvents and pesticides: recent evidence on male reproductive effects and biological markers. Occup Med (Lond) 2001;51:174-88.

7 Abell A, Ernst E, Bonde JP. Semen quality and sexual hormones in greenhouse workers. Second J Work Environ Health 2000;26:492-500.

8 Garey J, Wolff MS. Estrogenic and antiprogestagenic activities of pyrethroid insecticide. Biochem Biophy Res Commun 1998;251:855-9.

9 Mani U, Islam F, Prasad AK, et al. Steroidogenic alterations in testes and sera of rats exposed to formulated fenvalerate by inhalation. Hum Exp Toxicol 2002:21:593-7.

10 World Health Organisation. WHO laboratory manual for the examination of human semen and sperm-cervical mucus interaction, 4th edn. New York: Cambridge University Press, 1999.

11 Lahdetie J, Ajosenpaa-Saari M, Mykkanen J. Detection of aneuploidy in human spermatozoa of normal semen donors by fluorescence in situ hybridization. Environ Health Perspect 1996;104:620-32.

12 Martin RH. Detection of genetic damage in human sperm. Reprod Toxicol 1993;7:47-52.

13 Sun JG, Jurisicova A, Casper RF. Dectection of deoxyribonucleic acid fragmentation in human sperm: correlation with fertilization in vitro. Biol Reprod 1997;56:602-7.

14 Gavrieli Y, Sherman Y, Ben-Sasson SA. Identification of programmed cell death in situ via specific labeling of nuclear DNA fragmentation. J Cell Biol 1992:119:493-501.

15 Aravindan GR, Bjordahl J, Jost LK, et al. Susceptibility of human sperm to in situ DNA denaturation is strongly correlated with DNA strand breaks identified by single-cell electrophoresis. Exp Cell Res 1997;236:231-7.

16 Lopes S, Jurisicova A, Sun JG, et al. Reactive oxygen species: potential cause for DNA fragmentation in human spermatozoa. Hum Reprod 1998; 13:896-900.

17 Lopes S, Sun JG, Jurisicova A, et al. Sperm deoxyribonucleic acid fragmentation is increased in poor-quality semen samples and correlates with failed fertilization in intracytoplasmic sperm injection. Fertil Steril 1998;69:528-32.

18 Host E, Lindenberg S, Kahn JA, et al. DNA strand breaks in human sperm cells: a comparison between men with normal and oligozoospermic sperm samples. Acta Obstet Gynecol Scand 1999;78:336-9.

19 Hughes CM, Lewis SE, MeKelvey-Martin VJ, et al. The effects of antioxidant supplementation during percoll preparation on human sperm DNA integrity. Hum Reprod 1998;13:1240-7.

20 Donnelly ET, McClure N, Lewis SE. The effect of ascorbate and $\alpha$-tocopherol supplementation in vitro on DNA integrity and hydrogen peroxide-induced DNA damage in human spermatozoa. Mutagenesis 1999;14:505-11.

21 Singh NP. Microgel electrophoresis of DNA. In: Pfeifer GP, eds. Technologies for detection of DNA damage and mutations. New York: Plenum Press, 1996:3-24
22 Konca K, Lankoff A, Banasik A, et al. A cross-platform public domain PC image-analysis program for the Comet assay. Mutat Res 2003;534:15-20

23 Rojas $\mathbf{E}$, Lopez $M C$, Valverde $M$, et al. Single cell gel electrophoresis assay: methodology and applications. J Chromatogr 1999;722:225-54.

24 Oliva A, Spira A, Multigner L. Contribution of environmental factors to the risk of male infertility. Hum Reprod 2001;16:1768-76.

25 Swan SH, Brazil C, Drobnis EZ, et al. Geographic differences in semen quality of fertile U.S. males. Environ Health Perspect 2003;111:414-20.

26 Swan SH, Kruse RL, Lin F, et al. Semen quality in relation to biomarkers of pesticide exposure. Environ Health Perspect 2003;111:1478-84.

27 Padungtod C, Savitz DA, Overstreet JW, et al. Occupational pesticide exposure and semen quality among Chinese workers. J Occup Environ Med 2000;42:982-92

28 Ratnasooriya WD, Ratnayake SSK, Jayatunga YNA. Effects of pyrethroid insecticide ICON (lambda cyhalothrin) on reproductive competence of male rats. Asian J Andrology 2002;4:35-41.

29 Hu JY, Wang SL, Zhao RC, et al. Effects of fenvalerate on reproductive and endocrine systems of male rats. Natl J Androl 2002;8:18-21.

30 Lebailly $\mathbf{P}$, Vigrenx $\mathrm{C}$, Lechevrel $\mathrm{C}$, et al. DNA damage in mononuclear leucocytes of farmers measured using the alkaline Comet assay: modifications of DNA damage levels after a one day field spraying period with selected pesticides. Cancer Epidemiol Biomarkers Prev 1998;7:929-40.

31 Sakkas D, Mariethoz E, Manicardi G, et al. Origin of DNA damage in ejaculated human spermatozoa. Rev Reprod 1999:4:31-7.

32 Tesarik J, Greco E, Cohen-Bacrie P, et al. Germ cell apoptosis in men with complete and incomplete and incomplete spermiogenesis failure. Mol Hum Reprod 1998;4:757-62.

33 Host $E$, Lindenberg $S$, Ernst $E$, et al. DNA strand breaks in human spermatozoa: a possible factor, to be considered in couples suffering from unexplained infertility. Acta Obstet Gynecol Scand 1999;78:622-5.

34 Print CG, Loveland KL. Germ cell suicide: new insights into apoptosis during spermatogenesis. BioEssays 2000;22:423-30.

35 Twigg JP, Irvine DS, Aitken RJ. Oxidative damage to DNA in human spermatozoa does not preclude pronucleus formation at intracytoplasmic sperm injection. Hum Reprod 1998;13:1864-71.

36 Gandini L, Lombardo F, Paoli D, et al. Study of apoptotic DNA fragmentation in human spermatozoa. Hum Reprod 2000;15:830-9.

37 Hughes CM, Lewis SE, Mckelvey-Martin VJ, et al. A comparison of baseline and induced DNA damage in human spermatozoa from fertile and infertile men, using a modified Comet assay. Mol Hum Reprod 1996:2:613-19.

38 Irvine S, Twigg JP, Gordon EL, et al. DNA integrity in human spermatozoa: relationships with semen quality. J Androl 2000;21:33-44.

39 Aitken RJ, Gordon E, Harkiss D, et al. Relative impact of oxidative stress on the functional competence and genomic integrity of human spermatozoa. Biol Reprod 1998;59:1036-46.

40 Hughes CM, Lewis SE, Mckelvey-Martin VJ, et al. Reproducibility of human sperm DNA measurements using the alkaline single cell gel electrophoresis assay. Mutat Res 1997;374:261-8.

41 McKelvey-Martin VJ, Melia N, Walsh IK, et al. Two potential clinical applications of the alkaline single-cell gel electrophoresis assay: (1) human bladder washings and transitional cell carcinoma of the bladder; and (2) human sperm and male infertility. Mutat Res 1997;375:93-104. 